\title{
Monoclonal antibodies - a proven and rapidly expanding therapeutic modality for human diseases
}

\author{
Zhiqiang An ${ }^{凶}$ \\ Brown Foundation Institute of Molecular Medicine, University of Texas Health Science Center at Houston, Houston, TX 77030 , \\ USA \\ $\triangle$ Correspondence: Zhiqiang.an@uth.tmc.edu
}

Received March 10, 2010 Accepted March 31, 2010

\begin{abstract}
The study of antibodies has been a focal point in modern biology and medicine since the early 1900s. However, progress in therapeutic antibody development was slow and intermittent until recently. The first antibody therapy, murine-derived murononab OKT3 for acute organ rejection, was approved by the US Food and Drug Administration (FDA) in 1986, more than a decade after César Milstein and Georges Köhler developed methods for the isolation of mouse monoclonal antibodies from hybridoma cells in 1975. As a result of the scientific, technological, and clinical breakthroughs in the $1980 \mathrm{~s}$ and 1990s, the pace of therapeutic antibody discovery and development accelerated. Antibodies are becoming a major drug modality with more than two dozen therapeutic antibodies in the clinic and hundreds more in development. Despite the progress, need for improvement exists at every level. Antibody therapeutics provides fertile ground for protein scientists to fulfill the dream of personalized medicine through basic scientific discovery and technological innovation.
\end{abstract}

KEYWORDS monoclonal antibodies, personalized medicine, therapeutic antibodies

\section{INTRODUCTION}

The pioneering research by Robert Koch, Kitasato Shibasaburo, Emil von Behring, and Paul Ehrlich in late 19th and the early 20th centuries on the treatment of infectious diseases with serum from patients who had recovered from the same disease was the first use of antibodies as therapeutics. The active components in the serum were described as "antibodies" "antitoxins" and "magic bullets" (Ehrlich, 1908; Winau et al., 2004). This crude "serum therapy" was later modified by isolating antibodies from the serum for the treatment of infectious and immune diseases, known as intravenous immune globulin (IVIG) (Stangel and Pul, 2006). Despite the early success of serum therapy and IVIG treatment, no significant progress was made in therapeutic antibody discovery and development until César Milstein and Georges Köhler developed methods for isolating mouse monoclonal antibodies (mAbs) from hybridoma cells in 1975 (Köhler and Milstein, 1975). Since then, mAbs have not only fueled breakthrough discoveries in basic research, but have also been developed as clinical diagnostics, reagents for high throughput drug screening, and more importantly, life-saving medicines. The first therapeutic mAb murononab, a murinederived antibody for acute organ rejection, was approved by the US Food and Drug Administration (FDA) in 1986, a decade after the discovery of the mouse hybridoma technology (Thistlethwaite et al., 1987). As a result of technological breakthroughs in the 1980s and 1990s, progress in therapeutic mAbs field has been accelerated. Therapeutic antibodies have shown desirable safety profiles, high target specificity and affinity, and efficiency in disrupting protein/ protein interactions. They are becoming a major drug modality with more than 25 therapeutic antibodies in clinical use and hundreds more in development (Reichert and ValgeArcher, 2007; An, 2009).

\section{ANTIBODY STRUCTURE}

An antibody of the $\lg G$ isotype is a homodimer composed of two heterodimers of one light chain and one heavy chain. 
Both the heterodimers and homodimers are linked by inter chain disulphide bonds (Stanfield and Wilson, 2009) (Fig. 1A). The light and heavy chains each contain variable and constant regions. The antigen binding complementarity determining regions (CDRs) are short hypervariable amino acid sequences found in the variable domains of both light (variable light or VL) and heavy (variable heavy or VH) chains. Each VH and VL contains three pairs of non-identical CDRs (CDR1, CDR2 and CDR3). CDRs are termed hypervariable domains because the majority of the sequence variations associated with antibodies is found in the CDRs. Among the six CDRs in an IgG molecule, CDR3s have the greatest variability. The Fc-region (fragment crystalizable region) of a $\mathrm{mAb}$, residing in the constant regions of the heavy chains, can recruit effector cells such as natural killer cells, macrophages or neutrophils to activate the complement system to destroy the target-associated cells. These functions are referred to as antibody-dependent cellular cytotoxicity (ADCC) and complement-dependent cytotoxicity (CDC). Four additional antibody isotypes are found in humans, $\lg \mathrm{A}, \lg \mathrm{D}, \lg \mathrm{E}$, and $\lg \mathrm{M}$. All five isotypes share a common theme of a core heterodimer building unit of a heavy and light chain. In $\lg G, \lg A$ and $\lg D$ antibody isotypes, the $\mathrm{Fc}$ region is composed of two identical protein fragments, derived from the second $(\mathrm{CH} 2)$ and third $(\mathrm{CH} 3)$ constant domains of the antibody's two heavy chains. The $\mathrm{Fc}$ regions in $\lg \mathrm{M}$ and $\lg \mathrm{E}$ contain three heavy chain constant domains in each polypeptide chain. The IgG isotype is most commonly used in therapeutic applications.

\section{ANTIBODY THERAPEUTIC HISTORY}

The progress of antibody therapeutics is driven by both scientific and technological breakthroughs (Fig. 2). Therapeutic antibody development also parallels the desire of the industry to reduce immunogenicity. Immunogenicity can reduce the efficacy of therapeutic mAbs. In severe cases, immunogenicity can cause anaphylaxis and hypersensitivity reactions. Soon after the approval of the murine-derived monoclonal antibody murononab for acute organ rejection in 1986 (Thistlethwaite et al., 1987), it was realized that murinederived monoclonal antibodies are less than ideal therapeutics due to their high immunogenicity in humans. Several strategies to make antibodies more human, such as chimeric mAb (Morrison et al., 1984) and CDR grafting (Kettleborough et al., 1991), were devised to reduce the human anti-mouse antibody (HAMA) responses. It took a decade for the first chimeric mAb, abciximab for hemostasis, to be approved by FDA in 1994 (Faulds and Sorkin, 1994). The first humanized mAb, Zenapax for kidney transplant rejection, was approved for clinical use by FDA in 1997 (Vincenti et al., 1998). Humanization alleviated the HAMA response to various degrees, but many other drawbacks became evident. For

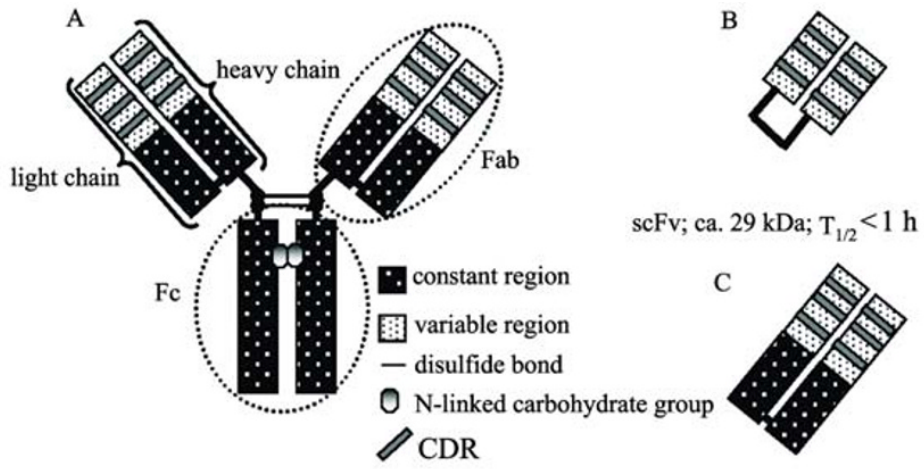

D

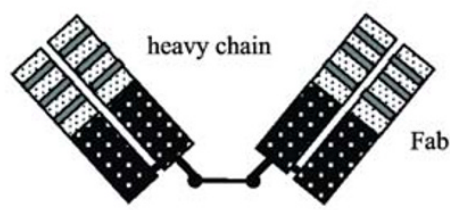

$\mathrm{F}\left(\mathrm{ab}^{\prime}\right) 2$; ca. $100 \mathrm{kDa} ; \mathrm{T}_{1 / 2} \sim 1 \mathrm{~h}$

IgG1, 2, 4; ca.145 kDa; $\mathrm{T}_{1 / 2}=7-20 \mathrm{~d} \quad$ Fab; ca. $50 \mathrm{kDa} ; \mathrm{T}_{1 / 2}<1 \mathrm{~h}$
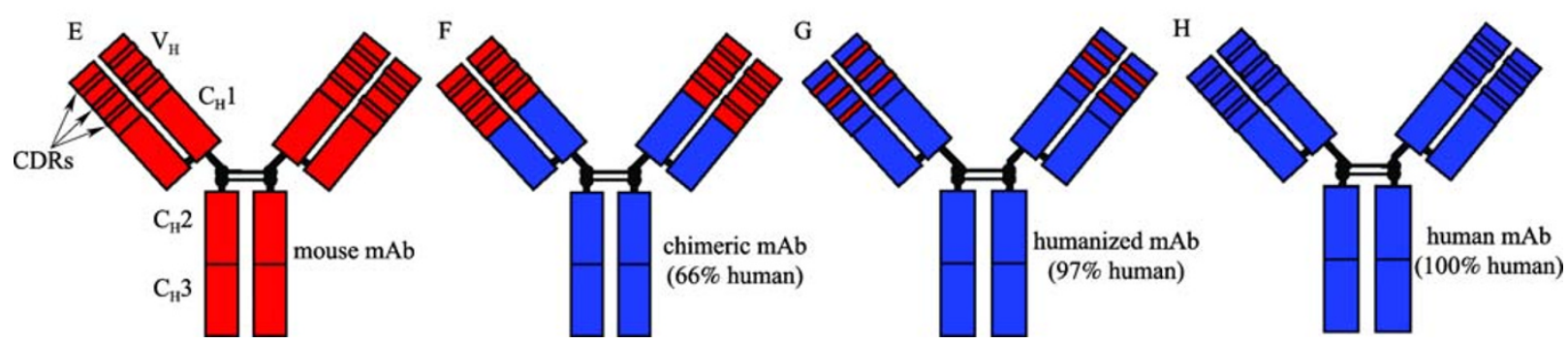

Figure 1. Diagrams of various antibody structures. (A) A generic lgG molecule. (B) A scFv fragment. (C) A Fab fragment. (D) A $F(a b ') 2$ fragment. (E) A mouse $\lg G$ molecule. (F) A murine:human chimeric $\lg G$ molecule. (G) A humanized IgG molecule. (H) A human IgG molecule. 
example, the humanization process is technically demanding and the process may result in reduced antigen binding affinity and decreased efficacy. To avoid the human immune response to murine-derived $\mathrm{mAbs}$ and to overcome the technical challenges associated with humanizing murine mAbs, two major approaches were developed for generating fully human mAbs. The first approach was to express human antibody fragments on bacteriophage surfaces. The resulting libraries contain billions of unique human antibody fragments which can be screened for leads (Vaughan et al., 1996). Humira, the first fully human mAb derived from a bacteriophage displayed antibody library, was approved by the FDA in 2003 for the treatment of rheumatoid arthritis (Weinblatt et al., 2003). The second approach was to use transgenic mice to produce fully human antibodies (Russell et al., 2000; Lonberg, 2005). This is achieved by replacing the mouse native antibody genes with their human counterparts. Vectibix, an anti-EGFR antibody approved for colorectal cancer therapy in 2006, was the first fully human antibody therapeutic derived from a transgenic mice system (Chua and Cunningham, 2006). The industry trend is to develop more human like antibodies for clinical use. However, immunogenicity is a complex biological process and it cannot be predicted solely on human content of an antibody. For example, Humira, a fully human antibody, has a relatively high incidence of immunogenicity (Bender et al., 2007). Surprisingly, there is little difference in immunogenicity (anti-antibody response) between humanized and chimeric mAbs in clinical use today (Table 1). Clearly more basic and clinical research is needed to develop reliable parameters to predict immunogenicity of therapeutic antibodies prior to their reaching the clinic.

\section{SOURCES OF THERAPEUTICS ANTIBODIES}

Accessing diversified antibody sources are paramount to the success in the discovery and development of antibody therapies. Most therapeutic antibodies in the clinic today are of murine origin largely due to the early availability of the mouse hybridoma technology; however, entirely mouse antibodies have poor pharmacokinetics in humans due to human anti-mouse antibody immune responses (Fig. 1E). To reduce immunogenicity, murine antibodies are commonly modified to murine/human chimeric antibodies or humanized antibodies for therapeutic applications (Carter, 2006; Reichert

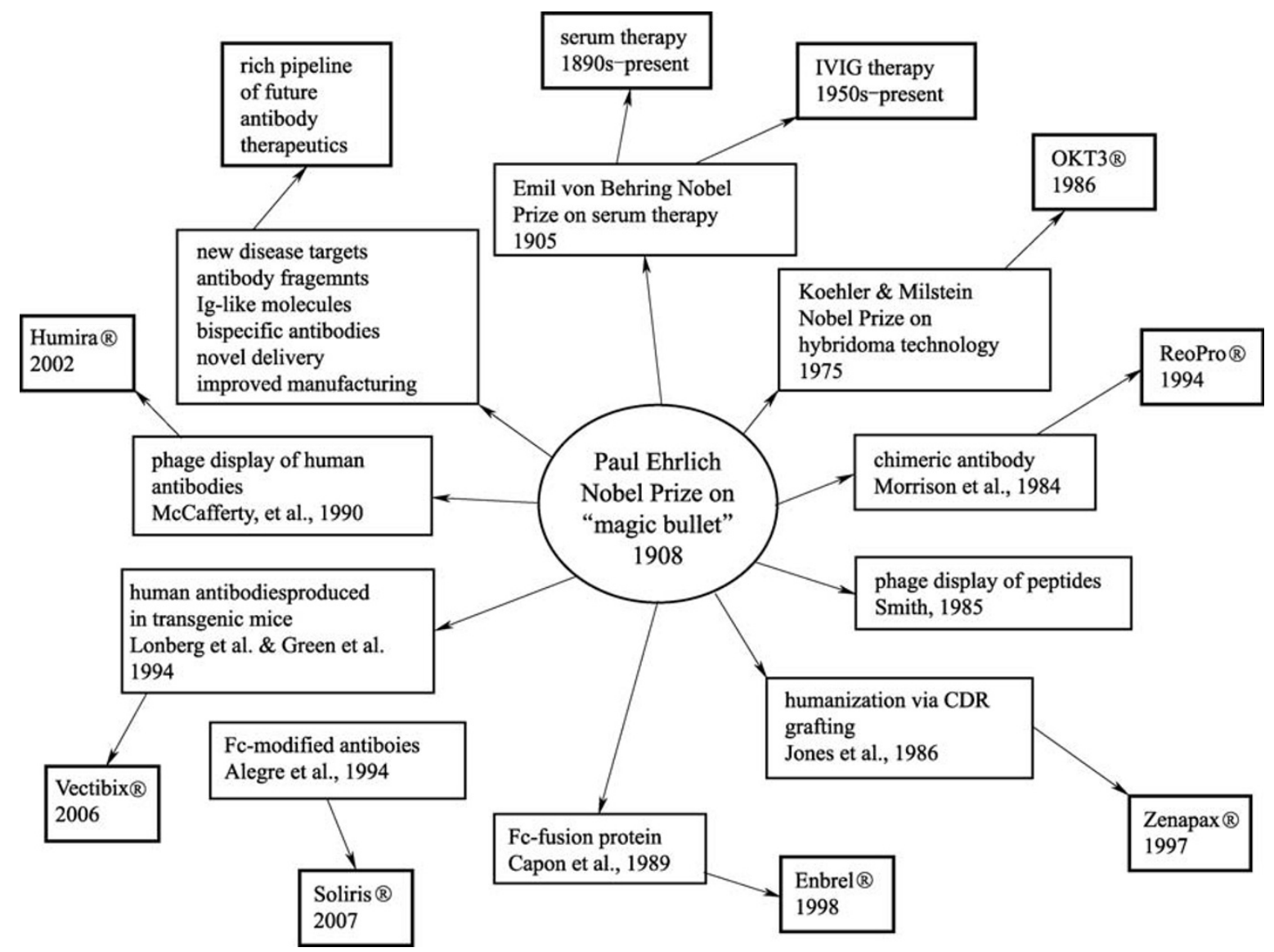

Figure 2. History of antibody therapeutics. Green boxes represent scientific and technology milestones. Blue boxes are antibody therapeutics developed as a result of the scientific and technology breakthroughs. 


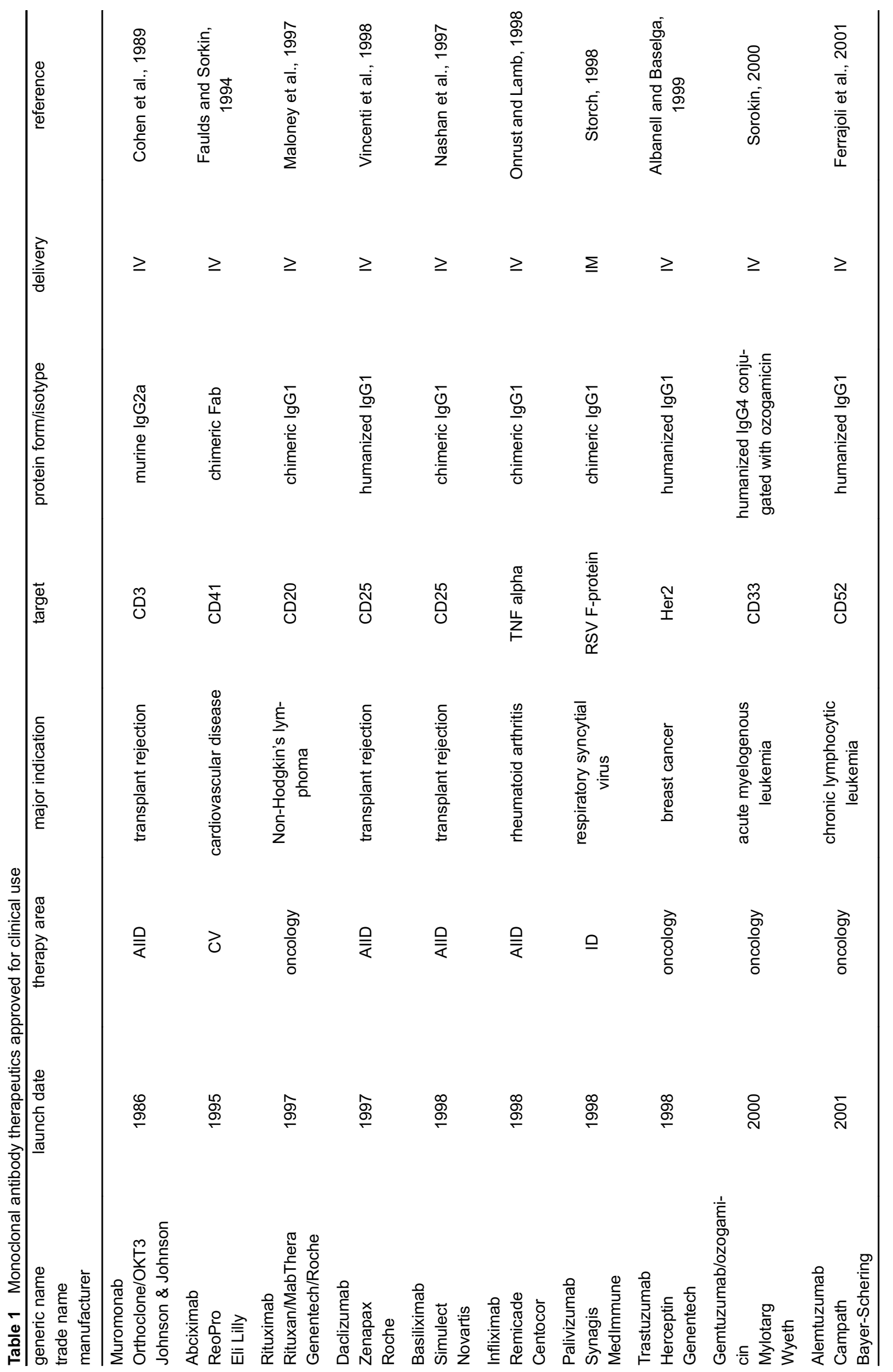




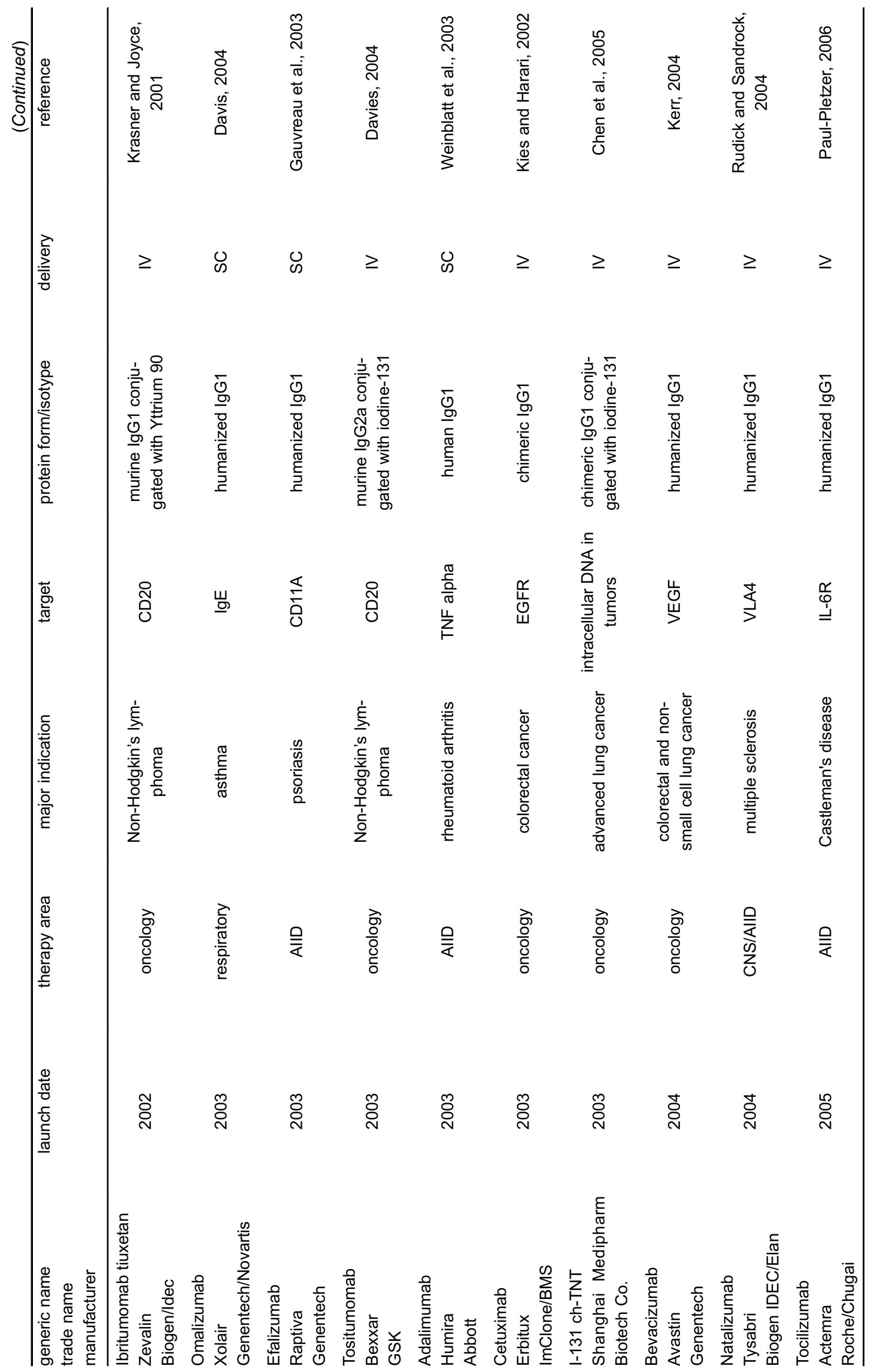




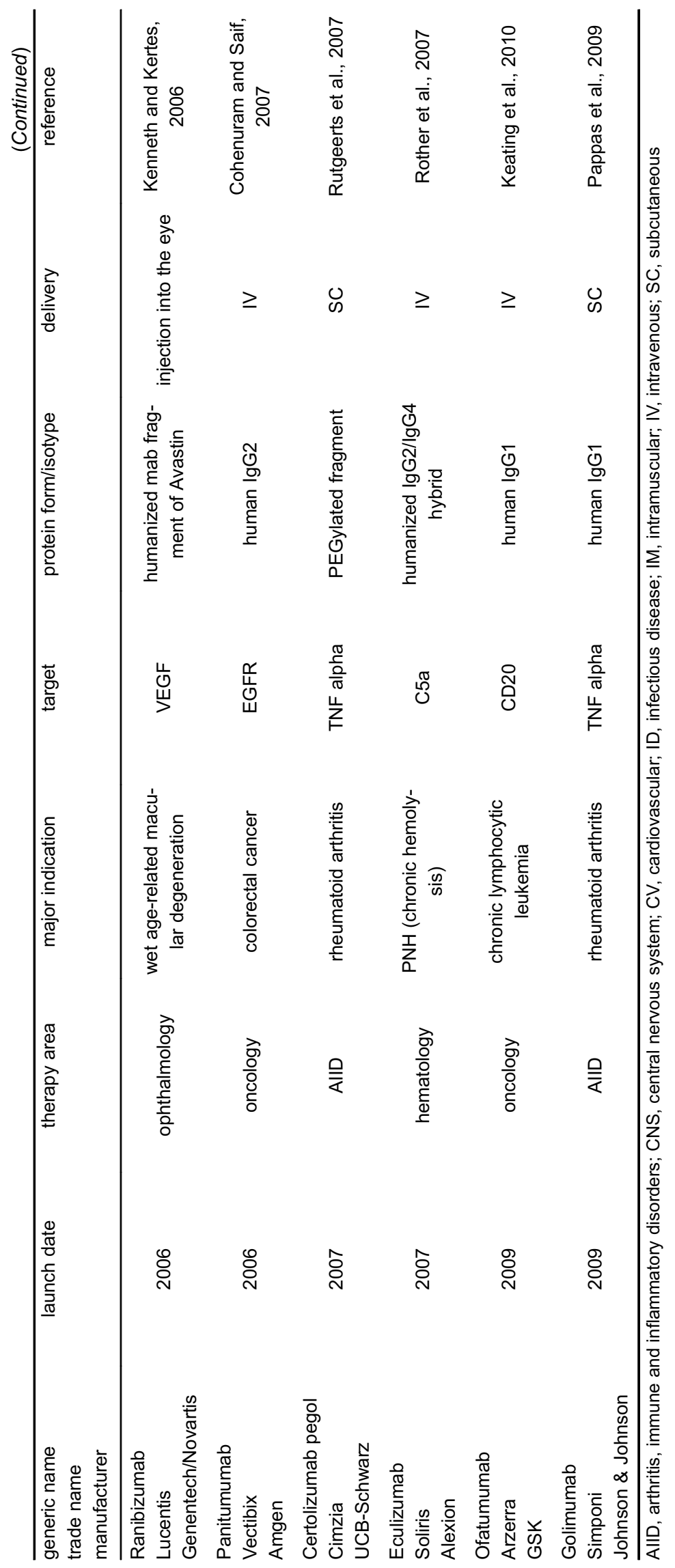


and Valge-Archer, 2007) (Fig. 1F-G). Later, transgenic mice and in vitro phage display were employed to generate fully human therapeutic antibodies to circumvent the immunogenicity issue associated with murine sequences (Fig. 1H) (Hoogenboom, 2005; Lonberg, 2005; Jakobovits et al., 2007; Lee et al., 2007). In addition to phage display, antibody fragments can also be displayed on yeast (Feldhaus et al., 2003), bacteria (Harvey et al., 2004), mammalian cells (Smith and Zauderer, 2009) and other in vitro systems such as ribosomes (Hanes et al., 1998). The pros and cons of the various antibody platforms have been broadly reviewed recently (An, 2009). The ever increasing demand for improved tools for antibody drug discovery will lead to new platforms and technologies. For example, humanized rabbit mAbs are being developed as therapeutics (News, 2010; Yu et al., 2010).

Another important source of antibodies is the human antibody $B$ cell repertoire. The isolation of human mAbs has been a labor-intensive endeavor, either through EBV immortalization or hybridoma fusion, or by constructing phagedisplayed antibody libraries (Vaughan et al., 1996; Traggiai et al., 2004; Li et al., 2006b; Rothe et al., 2007). Significant technological breakthroughs in B lymphocyte culture and cloning were reported recently including the analysis of HIV and flu mAbs in naturally infected or vaccinated humans (Wrammert et al., 2008; Jin et al., 2009; Ogunniyi et al., 2009; Scheid et al., 2009; Walker et al., 2009; Kwakkenbos et al., 2010). It is now possible to isolate human memory $B$ cells $(\mathrm{CD} 27+$, slgG + , IgD-) from peripheral blood mononuclear cells (PBMC), and more importantly, culture them where they proliferate and differentiate to IgG secreting cells (ISC) (Smith et al., 2009; Walker et al., 2009). Single cell culturing vessels have been engineered, thus enabling for high-throughput screening of functional mAbs (Jin et al., 2009; Ogunniyi et al., 2009). New methods of $B$ cell immortalization other than $E B V$ infection or hybridoma, such as $\mathrm{Bcl}-6 / \mathrm{Bcl}-\mathrm{xL}$, or hTERT, have been reported (Kwakkenbos et al., 2010). In addition, methods for cloning of IgG encoding genes from single $B$ cells have been optimized (Wrammert et al., 2008; Jin et al., 2009; Ogunniyi et al., 2009; Scheid et al., 2009; Walker et al., 2009; Kwakkenbos et al., 2010). These technical and engineering accomplishments make it feasible to isolate human mAbs with broad coverage of therapeutic targets.

\section{FORMATS OF ANTIBODY THERAPEUTICS}

Most therapeutic antibodies are full length IgG molecules and $\lg \mathrm{G} 1$ is the most commonly used sub-isotype (Table 1). This is because IgG1 molecules possess several favorable characteristics: they are structurally stable; they have a long in vivo half life; and IgG1 confer Fc-mediated biological effects. In designing antibody therapeutics, it is sometimes desirable to diminish or abolish the ADCC and CDC functions while retaining its pharmacokinetic profile, in the case of a "benign blocker" antibody. For this purpose, both $\lg G 2$ and $\lg G 4$ have been used in antibody therapeutics (Table 1). Protein engineering has been applied to create $\mathrm{Fc}$ with altered properties. For example, IgG2m4, a novel engineered IgG isotype with reduced $\mathrm{Fc}$ functionality was recently reported (An et al., 2009). The engineered IgG2m4 is based on the IgG2 isotype with four key amino acid residue changes derived from IgG4 (H268Q, V309L, A330S and P331S). An IgG2m4 antibody has an overall reduction in complement and $\mathrm{Fc} \gamma$ receptor binding in in vitro binding analyses while maintaining the normal in vivo serum half-life in rhesus monkeys.

In addition to IgG molecules, antibody fragments (e.g., Fab) have also been developed as therapeutics (Sandborn et al., 2007). Relative to IgG molecules, antibody fragments have more extensive penetration of tissues (particularly of solid tumors) due to their smaller size. The smaller size of antibody fragments has the advantage of accessing therapeutically important epitopes that may be sterically hindered. In addition, antibody fragments may be manufactured more cost effectively in a microbial fermentation system. The shorter half life of antibody fragments can be extended by modifying the molecules such as through PEGylation. The absence of the $\mathrm{Fc}$ region in an antibody fragment may lessen side effects caused by the interaction between $\mathrm{Fc}$ and the immune system. ReoPro, an anti-GPIIb/lla chimeric Fab for the prevention of blood clots in angioplasty, was the first antibody fragment approved for clinic use in the US (Faulds and Sorkin, 1994). Lucentis, a Fab fragment of Avastin, is used for the treatment of wet age-related macular degeneration (Kenneth and Kertes, 2006). More recently, Certolizumab pegol (Cimzia), a PEGylated antibody fragment, was approved for the treatment of rheumatoid arthritis in Europe (Rutgeerts et al., 2007). Currently, about 19 antibody fragment based therapeutics are in active clinical development (Nelson and Reichert, 2009).

Other antibody formats such as domain antibodies and single chain antibodies are also being explored for diagnostic and therapeutic applications (Holt et al., 2003; Holliger and Hudson, 2005; Enever et al., 2009). A PEGylated human antiIL-1R domain antibody is in clinical testing for the treatment of rheumatoid arthritis (Vk or VH dABs) (Enever et al., 2009). A llama nanoantibody targeting the von Willebrand factor is being developed for the treatment of thrombosis (Van Bockstaele et al., 2009).

Antibodies can also be used as carrier agents of small molecule toxins or radiolabeled isotopes, guiding drugs to specific disease sites and limiting undesired effects on healthy cells. This application is most commonly employed in oncology. At least two radiolabeled antibodies, Zevalin and Bexxar, are approved for clinical use (Table 1). These drugs are difficult to administer because a radiologist and an oncologist are needed to oversee the administration. Mylotarg, a humanized anti-CD33 IgG4 antibody conjugated to 
calicheamicin, is an example of antibody used to carry a cytotoxic payload (Table 1). Many challenges still exist in designing antibody:drug conjugates such as choice of linker, stoichiometry, and conjugation chemistry. Recent advances have resulted in linkers having increased stability in the bloodstream while allowing efficient payload release within the tumor cell (Ducry and Stump, 2010). Increasing evidence suggests that conjugated antibodies remain an effective alternative to $\mathrm{mAb}$, small molecule or radiolabeled isotope monotherapies.

It is interesting to note that the early antibody therapeutics started as crude polyclonals (serum therapy and IVIG) and the majority of today's antibody therapeutics is target-specific monoclonals. Progress is being made in developing recombinant polyclonal antibodies (rpAb) for the treatment or prophylaxis of human diseases (Pedersen et al., 2010). The difference is between IVIG and rpAbs is that rpAbs are mixtures of carefully selected monoclonal antibodies. Recombinant polyclonal antibodies (rpAb) mimic the natural human immune response in which the human body produces different types of antibodies targeting different epitopes of an antigen. This polyclonal response may have a better chance to neutralize the disease target than a single antibody does. One of the major challenges facing this approach is to manufacture the antibody cocktail consistently in both quantity and quality.

Today's monoclonal antibody therapeutics functions on a single disease target. It is advantageous if one antibody molecule can bind to two or more different targets since many complex diseases are the result of multiple mediators. Multispecificity has shown in naturally isolated antibodies, for example, the monoclonal IgE antibody SPE7 binds not only to its intended antigen 2,4-dinitrophenyl (DNP) hapten, but it also binds to several unrelated compounds with a broad range of affinities (James et al., 2003). More recently, antibodies that binds to both HER2 and VEGF were reported (Bostrom et al., 2009). In these cases, the multispecificity is conferred by a single binding pocket (James et al., 2003; Bostrom et al., 2009). Multispecifity antibodies are not common in nature, but they can be constructed by recombinant DNA methods (Kufer et al., 2004; Wu et al., 2007). Design of bispecifc antibodies is an active research area and the anti-IL-12/IL-18 dual-variable-domain immunoglobulin DVD-Ig molecule is an example of the many designs of bispecific antibodies (Wu et al., 2007).

\section{IMPACT OF POST-TRANSLATIONAL MODIFCATION ON THE PHYSICAL AND BIOLOGICAL PROPERTIES OF THERAPEUTIC ANTIBODIES}

Antibodies are large proteins which are subjected to extensive and complex posttranslational modifications, such as deamidation, glycosylation, N-terminal pyroglutamation, C-terminal lysine truncation, and methionine oxidation; and these posttranslational modifications profoundly impact the physical, chemical, and pharmacological properties of therapeutic antibodies (Wang et al., 2009). Oxidation of methionine residues is one of the most common protein degradation pathways including antibodies. In addition, methionine oxidation of recombinant monoclonal antibodies can alter their interaction with protein $A$ and protein $G$ resulting in a decrease in binding affinity (Gaza-Bulseco et al., 2008). The spontaneous nonenzymatic deamidation of glutaminyl and asparaginyl residues can alter the structure and function of therapeutic antibodies, potentially resulting in decreased bioactivity, as well as alterations in pharmacokinetics and antigenicity of antibody therapeutics (Huang et al., 2005). Among the various posttranslational processes, glycosylation has the broadest effect on biologic activity, protein conformation, stability, solubility, secretion, pharmacokinetics and immunogenicity of therapeutic antibodies (Arnold et al., 2007). For example, differential IgG sialylation may provide a switch from innate anti-inflammatory activity in the steadystate to generating adaptive pro-inflammatory effects upon antigenic challenge (Kaneko et al., 2006). Low fucose levels on antibodies enhance neutrophil- and mononuclear cellmediated ADCC (Peipp et al., 2008). Antibody glycoengineering is one of most active areas of research in therapeutic antibody discovery and development today (Mimura et al., 2009).

\section{MANUFACTURING}

Manufacturing of mAbs is expensive. A large scale facility can take multiple years and hundreds millions of dollars to build. Mammalian cell culture is the dominant production platform for $\mathrm{mAb}$ therapeutics. About half of the current marketed $\mathrm{mAbs}$ are expressed in Chinese hamster ovary ( $\mathrm{CHO}$ ) cell lines. Recombinant myelomas or hybridomas are still being used for antibody production, but their utility as a production platform is limited due to the low expression titer and instability of the cell lines. To reduce the cost of antibody production, other methods of antibody expression, such as bacteria, plants, transgenic animals (milk), eggs, and yeast, are being developed. Certolizumab pegol is an example of $\mathrm{mAb}$ (fragment) therapeutic made in a bacteria (Rutgeerts et al., 2007). However, antibodies produced in E. coli are not glycosylated and this severely limits its use as a manufacturing platform. Antibodies with specific human N-glycan structures have been expressed in glycoengineered lines of the yeast Pichia pastoris and its utility as a general platform for producing recombinant antibodies with human N-glycosylation is being developed ( $\mathrm{Li}$ et al., 2006a; Lin et al., 2010). Antibody has been expressed in engineered chicken eggs and in plants (Zhu et al., 2005; Cox et al., 2006). Despite significant effort, cost saving alternative antibody manufacturing platforms is still lacking. This is in part due to the effect of the various expression hosts on antibody posttranslational 
modifications and the low production titers. There is a clear need for innovation and technology breakthroughs in reducing the manufacturing cost of therapeutic antibodies. This is not limited to the choice of expression hosts. Purification, formulation, storage, and other steps in the entire manufacturing process need to be improved to bring antibody therapeutics in a more cost competitive position against small molecule drugs.

\section{ANTIBODY THERAPEUTIC TARGETS}

Antibodies can engage a wide range of extracellular drug targets such as membrane bound proteins or circulating ligands and cytokines (Table 1). Even though antibodies do not readily cross cell membranes or the brain blood barrier (BBB), about $80 \%$ of the current druggable targets are accessible to antibodies (Strohl, 2009). Extracellular signaling (ECS) drug targets generally are not modulated by small molecules as ECS targets typically function through proteinprotein interactions. ECS proteins have been successfully targeted by antibodies. The therapeutic areas in which antibodies have the strongest presence, in terms of marketed products and developmental research, are oncology and Arthritis, immune and inflammatory disorders (AIID). Of the more than 200 monoclonal antibodies in clinical use and development today, about half are being developed for oncology. The second largest therapeutic category is in the AIID area, and infectious disease is fast becoming a major disease area for antibody therapeutics. While the emphasis on oncology and AIID therapeutic areas will continue, antibody therapeutics are being developed in almost all disease areas such as central nervous system, cardiovascular, women's health, diabetes/endocrinology, hematology, ophthalmology, and respiratory diseases (Strohl, 2009).

\section{SUMMARY}

Antibody therapeutics represent a major breakthrough in combating human diseases and the improvement of human health. This is reflected by the recent trend in drug discovery and development. In 2000, nine of the top 10 medicines were small molecules while only one was a recombinant protein but by 2008 , a short eight years later, half of the top 10 medicines are recombinant proteins and antibodies. This trend will continue as about $50 \%$ of the new drugs in various stages of clinical development are antibodies. Despite the remarkable progress, many scientific, technological, and clinical challenges remain in the area of therapeutic antibody discovery and development. Opportunities for innovation exist at every level: accessing difficult antibody targets (such as G proteincoupled receptors), novel antibody sources and formats, crossing the BBB and cell membranes, modified effector functions, improved formulation and delivery methods, and lower cost manufacturing, to name a few.

\section{ABBREVIATIONS}

AIID, arthritis, immune and inflammatory disorders; ADCC, antibodydependent cellular cytotoxicity; BBB, brain blood barrier; CDC, complement-dependent cytotoxicity; CDRs, complementarity determining regions; DNP, 2,4-dinitrophenyl; ECS, extracellular signaling; FDA, Food and Drug Administration; HAMA, human anti-mouse antibody; IM, intramuscular; ISC, IgG secreting cells; IV, intravenous; IVIG, intravenous immune globulin; mAbs, mouse monoclonal antibodies; PBMC, peripheral blood mononuclear cells; rpAb, recombinant polyclonal antibodies; SC, subcutaneous; VL, variable light; VH, variable heavy

\section{REFERENCES}

Albanell, J., and Baselga, J. (1999). Trastuzumab, a humanized antiHER2 monoclonal antibody, for the treatment of breast cancer. Drugs Today (Barc) 35, 931-946.

An, Z. (2009). Therapeutic monoclonal antibodies: from bench to clinic, Hoboken, NJ: John Wiley and Sons.

An, Z., Forrest, G., Moore, R., Cukan, M., Haytko, P., Huang, L., Vitelli, S., Zhao, J.Z., Lu, P., Hua, J., et al. (2009). IgG2m4, an engineered antibody isotype with reduced Fc function. MAbs 1, 572-579.

Arnold, J.N., Wormald, M.R., Sim, R.B., Rudd, P.M., and Dwek, R.A. (2007). The impact of glycosylation on the biological function and structure of human immunoglobulins. Annu Rev Immunol 25, 21-50.

Bender, N.K., Heilig, C.E., Dröll, B., Wohlgemuth, J., Armbruster, F.P., and Heilig, B. (2007). Immunogenicity, efficacy and adverse events of adalimumab in RA patients. Rheumatol Int 27, 269-274.

Bostrom, J., Yu, S.F., Kan, D., Appleton, B.A., Lee, C.V., Billeci, K., Man, W., Peale, F., Ross, S., Wiesmann, C., et al. (2009). Variants of the antibody herceptin that interact with HER2 and VEGF at the antigen binding site. Science 323, 1610-1614.

Carter, P.J. (2006). Potent antibody therapeutics by design. Nat Rev Immunol 6, 343-357.

Chen, S., Yu, L., Jiang, C., Zhao, Y., Sun, D., Li, S., Liao, G., Chen, Y., Fu, Q., Tao, Q., et al. (2005). Pivotal study of iodine-131-labeled chimeric tumor necrosis treatment radioimmunotherapy in patients with advanced lung cancer. J Clin Oncol 23, 1538-1547.

Chua, Y.J., and Cunningham, D. (2006). Panitumumab. Drugs Today (Barc) 42, 711-719.

Cohen, D.J., Benvenisty, A.I., Cianci, J., and Hardy, M.A. (1989). OKT3 prophylaxis in cadaveric kidney transplant recipients with delayed graft function. Am J Kidney Dis 14, 19-27.

Cohenuram, M., and Saif, M.W. (2007). Panitumumab the first fully human monoclonal antibody: from the bench to the clinic. Anticancer Drugs 18, 7-15.

Cox, K.M., Sterling, J.D., Regan, J.T., Gasdaska, J.R., Frantz, K.K., Peele, C.G., Black, A., Passmore, D., Moldovan-Loomis, C., Srinivasan, M., et al. (2006). Glycan optimization of a human monoclonal antibody in the aquatic plant Lemna minor. Nat Biotechnol 24, 1591-1597.

Davies, A.J. (2004). Tositumomab and iodine [131I] tositumomab in the management of follicular lymphoma. An oncologist's view. Q J Nucl Med Mol Imaging 48, 305-316.

Ducry, L., and Stump, B. (2010). Antibody-drug conjugates: linking 
cytotoxic payloads to monoclonal antibodies. Bioconjug Chem 21, 5-13.

Ehrlich, P. (1908). Partial cell functions-Nobel lecture, December 11, 1908 in Physiology or Medicine: including presentation speeches and laureates' biographies. Amsterdam, 1967: Elsevier Publisher.

Enever, C., Batuwangala, T., Plummer, C., and Sepp, A. (2009). Next generation immunotherapeutics-honing the magic bullet. Curr Opin Biotechnol 20, 405-411.

Faulds, D., and Sorkin, E.M. (1994). Abciximab (c7E3 Fab). A review of its pharmacology and therapeutic potential in ischaemic heart disease. Drugs 48, 583-598.

Feldhaus, M.J., Siegel, R.W., Opresko, L.K., Coleman, J.R., Feldhaus, J.M., Yeung, Y.A., Cochran, J.R., Heinzelman, P., Colby, D., Swers, J., et al. (2003). Flow-cytometric isolation of human antibodies from a nonimmune Saccharomyces cerevisiae surface display library. Nat Biotechnol 21, 163-170.

Ferrajoli, A., O'Brien, S., and Keating, M.J. (2001). Alemtuzumab: a novel monoclonal antibody. Expert Opin Biol Ther 1, 1059-1065.

Gaza-Bulseco, G., Faldu, S., Hurkmans, K., Chumsae, C., and Liu, H. (2008). Effect of methionine oxidation of a recombinant monoclonal antibody on the binding affinity to protein $A$ and protein G. J Chromatogr B Analyt Technol Biomed Life Sci 870, 55-62.

Gauvreau, G.M., Becker, A.B., Boulet, L.P., Chakir, J., Fick, R.B., Greene, W.L., Killian, K.J., O'Byrne P, M., Reid, J.K., and Cockcroft, D.W. (2003). The effects of an anti-CD11a mAb, efalizumab, on allergen-induced airway responses and airway inflammation in subjects with atopic asthma. J Allergy Clin Immunol 112, 331-338.

Hanes, J., Jermutus, L., Weber-Bornhauser, S., Bosshard, H.R., and Plückthun, A. (1998). Ribosome display efficiently selects and evolves high-affinity antibodies in vitro from immune libraries. Proc Natl Acad Sci U S A 95, 14130-14135.

Harvey, B.R., Georgiou, G., Hayhurst, A., Jeong, K.J., Iverson, B.L., and Rogers, G.K. (2004). Anchored periplasmic expression, a versatile technology for the isolation of high-affinity antibodies from Escherichia coli-expressed libraries. Proc Natl Acad Sci U S A 101, 9193-9198.

Holliger, P., and Hudson, P.J. (2005). Engineered antibody fragments and the rise of single domains. Nat Biotechnol 23, 1126-1136.

Holt, L.J., Herring, C., Jespers, L.S., Woolven, B.P., and Tomlinson, I. M. (2003). Domain antibodies: proteins for therapy. Trends Biotechnol 21, 484-490.

Hoogenboom, H.R. (2005). Selecting and screening recombinant antibody libraries. Nat Biotechnol 23, 1105-1116.

Huang, L., Lu, J., Wroblewski, V.J., Beals, J.M., and Riggin, R.M. (2005). In vivo deamidation characterization of monoclonal antibody by LC/MS/MS. Anal Chem 77, 1432-1439.

Jakobovits, A., Amado, R.G., Yang, X., Roskos, L., and Schwab, G. (2007). From XenoMouse technology to panitumumab, the first fully human antibody product from transgenic mice. Nat Biotechnol 25, 1134-1143.

James, L.C., Roversi, P., and Tawfik, D.S. (2003). Antibody multispecificity mediated by conformational diversity. Science 299, 1362-1367.

Jin, A., Ozawa, T., Tajiri, K., Obata, T., Kondo, S., Kinoshita, K., Kadowaki, S., Takahashi, K., Sugiyama, T., Kishi, H., et al. (2009). $A$ rapid and efficient single-cell manipulation method for screening antigen-specific antibody-secreting cells from human peripheral blood. Nat Med 15, 1088-1092.

Kaneko, Y., Nimmerjahn, F., and Ravetch, J.V. (2006). Antiinflammatory activity of immunoglobulin $G$ resulting from $F c$ sialylation. Science 313, 670-673.

Kenneth, T.E., and Kertes, P.J. (2006). Ranibizumab in neovascular age-related macular degeneration. Clin Interv Aging 1, 451-466.

Kerr, D.J. (2004). Targeting angiogenesis in cancer: clinical development of bevacizumab. Nat Clin Pract Oncol 1, 39-43.

Kettleborough, C.A., Saldanha, J., Heath, V.J., Morrison, C.J., and Bendig, M.M. (1991). Humanization of a mouse monoclonal antibody by CDR-grafting: the importance of framework residues on loop conformation. Protein Eng 4, 773-783.

Keating, M.J., Dritselis, A., Yasothan, U., and Kirkpatrick, P. (2010). Ofatumumab. Nat Rev Drug Discov 9, 101-102.

Kies, M.S., and Harari, P.M. (2002). Cetuximab (Imclone/Merck/ Bristol-Myers Squibb). Curr Opin Investig Drugs 3, 1092-1100.

Köhler, G., and Milstein, C. (1975). Continuous cultures of fused cells secreting antibody of predefined specificity. Nature 256, 495 497.

Krasner, C., and Joyce, R.M. (2001). Zevalin: 90yttrium labeled antiCD20 (ibritumomab tiuxetan), a new treatment for non-Hodgkin's lymphoma. Curr Pharm Biotechnol 2, 341-349.

Kufer, P., Lutterbüse, R., and Baeuerle, P.A. (2004). A revival of bispecific antibodies. Trends Biotechnol 22, 238-244.

Kwakkenbos, M.J., Diehl, S.A., Yasuda, E., Bakker, A.Q., van Geelen, C.M., Lukens, M.V., van Bleek, G.M., Widjojoatmodjo, M.N., Bogers, W.M., Mei, H., et al. (2010). Generation of stable monoclonal antibody-producing $B$ cell receptor-positive human memory B cells by genetic programming. Nat Med 16, 123-128.

Lee, C.M., Iorno, N., Sierro, F., and Christ, D. (2007). Selection of human antibody fragments by phage display. Nat Protoc 2, 3001-3008.

Li, H., Sethuraman, N., Stadheim, T.A., Zha, D., Prinz, B., Ballew, N., Bobrowicz, P., Choi, B.K., Cook, W.J., Cukan, M., et al. (2006a). Optimization of humanized IgGs in glycoengineered Pichia pastoris. Nat Biotechnol 24, 210-215.

Li, J., Sai, T., Berger, M., Chao, Q., Davidson, D., Deshmukh, G., Drozdowski, B., Ebel, W., Harley, S., Henry, M., et al. (2006b). Human antibodies for immunotherapy development generated via a human B cell hybridoma technology. Proc Natl Acad Sci U S A 103, 3557-3562.

Lin, S., Shen, Z., Zha, D., Sharkey, N., Prinz, B., Hamilton, S., Pavoor, T.V., Bobrowicz, B., Shaikh, S.S., Rittenhour, A.M., et al. (2010). Selection of Pichia pastoris strains expressing recombinant immunoglobulin $\mathrm{G}$ by cell surface labeling. J Immunol Methods.

Lonberg, N. (2005). Human antibodies from transgenic animals. Nat Biotechnol 23, 1117-1125.

Maloney, D.G., Grillo-Lopez, A.J., White, C.A., Bodkin, D., Schilder, R.J., Neidhart, J.A., Janakiraman, N., Foon, K.A., Liles, T.M., Dallaire, B.K., et al. (1997). IDEC-C2B8 (Rituximab) anti-CD20 monoclonal antibody therapy in patients with relapsed low-grade non-Hodgkin's lymphoma. Blood 90, 2188-2195.

Mimura, Y., Jefferis, R., Mimura-Kimura, Y., Abrahams, J., and Rudd, P.M. (2009). Glycosylation of Therapeutic IgGs. In Therapeutic Monoclonal Antibodies: from Bench to Clinic, An, Z. (ed), pp 67-89. Hoboken, NJ: John Wiley and Sons, Inc.

Morrison, S.L., Johnson, M.J., Herzenberg, L.A., and Oi, V.T. (1984). Chimeric human antibody molecules: mouse antigen-binding domains with human constant region domains. Proc Natl Acad 
Sci U S A 81, 6851-6855.

Nashan, B., Moore, R., Amlot, P., Schmidt, A.G., Abeywickrama, K., and Soulillou, J.P. (1997). Randomised trial of basiliximab versus placebo for control of acute cellular rejection in renal allograft recipients. CHIB 201 International Study Group. Lancet 350, 1193-1198.

Nelson, A.L., and Reichert, J.M. (2009). Development trends for therapeutic antibody fragments. Nat Biotechnol 27, 331-337.

News (2010). Deal watch: BMS acquires rights for IL-6 inhibitor. Nat Rev Drug Discov 9, 10.

Ogunniyi, A.O., Story, C.M., Papa, E., Guillen, E., and Love, J.C. (2009). Screening individual hybridomas by microengraving to discover monoclonal antibodies. Nat Protoc 4, 767-782.

Onrust, S.V., and Lamb, H.M. (1998). Infliximab: a review of its use in Crohn's disease and rheumatoid arthritis. BioDrugs 10, 397-422.

Pappas, D.A., Bathon, J.M., Hanicq, D., Yasothan, U., and Kirkpatrick, P. (2009). Golimumab. Nat Rev Drug Discov 8, 695-696.

Paul-Pletzer, K. (2006). Tocilizumab: blockade of interleukin-6 signaling pathway as a therapeutic strategy for inflammatory disorders. Drugs Today (Barc) 42, 559-576.

Pedersen, M.W., Jacobsen, H.J., Koefoed, K., Hey, A., Pyke, C., Haurum, J.S., and Kragh, M. (2010). Sym004: a novel synergistic anti-epidermal growth factor receptor antibody mixture with superior anticancer efficacy. Cancer Res 70, 588-597.

Peipp, M., Lammerts van Bueren, J.J., Schneider-Merck, T., Bleeker, W.W., Dechant, M., Beyer, T., Repp, R., van Berkel, P.H., Vink, T., van de Winkel, J.G., et al. (2008). Antibody fucosylation differentially impacts cytotoxicity mediated by NK and PMN effector cells. Blood 112, 2390-2399.

Reichert, J.M., and Valge-Archer, V.E. (2007). Development trends for monoclonal antibody cancer therapeutics. Nat Rev Drug Discov 6, 349-356.

Rothe, C., Urlinger, S., Lohning, C., Prassler, J., Stark, Y., Jager, U., Hubner, B., Bardroff, M., Pradel, I., Boss, M., et al. (2007). The human combinatorial antibody library HuCAL GOLD combines diversification of all six CDRs according to the natural immune system with a novel display method for efficient selection of highaffinity antibodies. J Mol Biol 376, 1182-1200.

Rother, R.P., Rollins, S.A., Mojcik, C.F., Brodsky, R.A., and Bell, L. (2007). Discovery and development of the complement inhibitor eculizumab for the treatment of paroxysmal nocturnal hemoglobinuria. Nat Biotechnol 25, 1256-1264.

Rudick, R.A., and Sandrock, A. (2004). Natalizumab: alpha 4-integrin antagonist selective adhesion molecule inhibitors for MS. Expert Rev Neurother 4, 571-580.

Russell, N.D., Corvalan, J.R., Gallo, M.L., Davis, C.G., and Pirofski, L. (2000). Production of protective human antipneumococcal antibodies by transgenic mice with human immunoglobulin loci. Infect Immun 68, 1820-1826.

Rutgeerts P, Schreiber S, Feagan B, Keininger D.L., O'Neil L., Fedorak R.N. (2007) Certolizumab pegol, a monthly subcutaneously administered Fc-free anti-TNFalpha, improves healthrelated quality of life in patients with moderate to severe Crohn's disease. Int J Colorectal Dis 23, 289-296.

Sandborn, W.J., Feagan, B.G., Stoinov, S., Honiball, P.J., Rutgeerts, P., Mason, D., Bloomfield, R., Schreiber, S., and the PRECISE 1 Study Investigators. (2007). Certolizumab pegol for the treatment of Crohn's disease. N Engl J Med 357, 228-238.

Scheid, J.F., Mouquet, H., Feldhahn, N., Seaman, M.S., Velinzon, K., Pietzsch, J., Ott, R.G., Anthony, R.M., Zebroski, H., Hurley, A., et al. (2009). Broad diversity of neutralizing antibodies isolated from memory B cells in HIV-infected individuals. Nature 458, 636-640.

Smith, E.S., and Zauderer, M. (2009) Antibody selection from immunoglobulin libraries expressed in mammalian cells. In therapeutic monoclonal antibodies: from bench to clinic, An, Z. (ed), pp 283-307. Hoboken, NJ: John Wiley \& Sons.

Smith, K., Garman, L., Wrammert, J., Zheng, N.Y., Capra, J.D., Ahmed, R., and Wilson, P.C. (2009). Rapid generation of fully human monoclonal antibodies specific to a vaccinating antigen. Nat Protoc 4, 372-384.

Sorokin, P. (2000). Mylotarg approved for patients with CD33 + acute myeloid leukemia. Clin J Oncol Nurs 4, 279-280.

Stanfield, R.L., and Wilson, I.A. (2009). Antibody molecular structure. In therapeutic monoclonal antibodies: from bench to clinic, An, Z. (ed), pp 889. Hoboken, NJ: John Wiley \& Sons, Inc.

Stangel, M., and Pul, R. (2006). Basic principles of intravenous immunoglobulin (IVIg) treatment. J Neurol 253, V18-24.

Storch, G.A. (1998). Humanized monoclonal antibody for prevention of respiratory syncytial virus infection. Pediatrics 102, 648-651.

Strohl, W.R. (2009). Therapeutic monoclonal antibodies: past, present, and future. In therapeutic monoclonal antibodies: from bench to clinic, An, Z. (ed), pp 889. Hoboken, NJ: John Wiley \& Sons, Inc.

Thistlethwaite, J.R. Jr, Haag, B.W., Gaber, A.O., Stuart, J.K., Aronson, A.J., Mayes, J.T., Lloyd, D.M., and Stuart, F.P. (1987). The use of OKT3 to treat steroid-resistant renal allograft rejection in patients receiving cyclosporine. Transplant Proc 19, 1901-1904.

Traggiai, E., Becker, S., Subbarao, K., Kolesnikova, L., Uematsu, Y., Gismondo, M.R., Murphy, B.R., Rappuoli, R., and Lanzavecchia, A. (2004). An efficient method to make human monoclonal antibodies from memory $B$ cells: potent neutralization of SARS coronavirus. Nat Med 10, 871-875.

Van Bockstaele, F., Holz, J.B., and Revets, H. (2009). The development of nanobodies for therapeutic applications. Curr Opin Investig Drugs 10, 1212-1224.

Vaughan, T.J., Williams, A.J., Pritchard, K., Osbourn, J.K., Pope, A. R., Earnshaw, J.C., McCafferty, J., Hodits, R.A., Wilton, J., and Johnson, K.S. (1996). Human antibodies with sub-nanomolar affinities isolated from a large non-immunized phage display library. Nat Biotechnol 14, 309-314.

Vincenti, F., Kirkman, R., Light, S., Bumgardner, G., Pescovitz, M., Halloran, P., Neylan, J., Wilkinson, A., Ekberg, H., Gaston, R., et al. (1998). Interleukin-2-receptor blockade with daclizumab to prevent acute rejection in renal transplantation. $\mathrm{N}$ Engl J Med 338, 161-165.

Walker, L.M., Phogat, S.K., Chan-Hui, P.Y., Wagner, D., Phung, P., Goss, J.L., Wrin, T., Simek, M.D., Fling, S., Mitcham, J.L., et al. (2009). Broad and potent neutralizing antibodies from an African donor reveal a new HIV-1 vaccine target. Science 326, 285-289.

Wang, Y., Washabaugh, M.W., and Zhao, Q.J. (2009). Characterization of heterogeneity in monoclonal antibody products. In characterization of heterogeneity in monoclonal antibody products, An, Z. (ed), pp 541-554. Hoboken, NJ: John Wiley and Sons.

Weinblatt, M.E., Keystone, E.C., Furst, D.E., Moreland, L.W., Weisman, M.H., Birbara, C.A., Teoh, L.A., Fischkoff, S.A., and 
Chartash, E.K. (2003). Adalimumab, a fully human anti-tumor necrosis factor alpha monoclonal antibody, for the treatment of rheumatoid arthritis in patients taking concomitant methotrexate: the ARMADA trial. Arthritis Rheum 48, 35-45.

Winau, F., Westphal, O., and Winau, R. (2004). Paul Ehrlich-in search of the magic bullet. Microbes Infect 6, 786-789.

Wrammert, J., Smith, K., Miller, J., Langley, W.A., Kokko, K., Larsen, C., Zheng, N.Y., Mays, I., Garman, L., Helms, C., et al. (2008). Rapid cloning of high-affinity human monoclonal antibodies against influenza virus. Nature 453, 667-671.

Wu, C., Ying, H., Grinnell, C., Bryant, S., Miller, R., Clabbers, A.,
Bose, S., McCarthy, D., Zhu, R.R., Santora, L., et al. (2007). Simultaneous targeting of multiple disease mediators by a dualvariable-domain immunoglobulin. Nat Biotechnol 25, 1290-1297.

Yu, Y.L., Lee, P., Ke, Y.H., Zhang, Y.K., Yu, Q., Lee, J., Li, M.Z., Song, J.L., Chen, J.G., Dai, J.H., et al. (2010). A humanized anti-VEGF rabbit monoclonal antibody inhibits angiogenesis and blocks tumor growth in xenograft models. PLoS One 5, e9072.

Zhu, L., van de Lavoir, M.C., Albanese, J., Beenhouwer, D.O., Cardarelli, P.M., Cuison, S., Deng, D.F., Deshpande, S., Diamond, J. H., Green, L., et al. (2005). Production of human monoclonal antibody in eggs of chimeric chickens. Nat Biotechnol 23, 1159-1169. 